\title{
Impact of accumulating drifting macroalgae on a shallow-water sediment system: an experimental study
}

\author{
Kristina Sundbäck ${ }^{1}$, Benno Jönsson ${ }^{1, *}$, Per Nilsson $^{2, *}$, Inger Lindström $^{1}$ \\ ${ }^{1}$ Department of Marine Botany, University of Göteborg, Carl Skottbergs Gata 22, S-413 19 Göteborg, Sweden \\ ${ }^{2}$ Department of Zoology, University of Göteborg, PO Box 25059, S-400 31 Göteborg, Sweden
}

\begin{abstract}
Using an outdoor flow-through experimental set-up consisting of twelve $30 \mathrm{l}$ containers, effect of accumulation of drifting filamentous macroalgae on a shallow-water sediment system was studied for $3 \mathrm{wk}$ after the addition of 0.9 (low dose) and $1.8 \mathrm{~kg}$ fresh $\mathrm{wt} \mathrm{m}^{-2}$ (high dose) of filamentous red algae. Estimates of structural changes were based on relationships between numbers and biomass of bacteria, autotrophic microflora, ciliates and meiofauna and their qualitative composition. Effects on the functional level were assessed by measuring primary productivity, changes in carbon pools, as well as oxygen and nutrient flux. The low-dose treatment did not significantly alter the composition or patterns of primary productivity and nutrient fluxes when compared with the control (no addition). The high-dose addition decreased the abundance of microalgae, ciliates and meiofauna, whereas no clear trend was seen for bacteria relative to the control. From the oxygen flux values it was apparent that the systems in control and low-dose containers were autotrophic $(P>R)$, whereas in the high-dose treatments the oxygen concentration fell sharply, exhibiting a net oxygen consumption most of the time due to fast mineralization of the macroalgal biomass. The ammonium concentration increased significantly (maximum mean rate $1.4 \mathrm{mmol} \mathrm{m} \mathrm{m}^{-2} \mathrm{~d}^{-1}$ ) and concomitantly with low oxygen values. The content of particulate organic carbon (POC) in the top $5 \mathrm{~mm}$ sediment increased by $2 \mathrm{~g} \mathrm{~m}^{-2}$ in both control and low-dose containers due to increased meiofaunal biomass, while in the high-dose treatments the POC content decreased by $2.3 \mathrm{~g} \mathrm{~m}^{-2}$ From the results it appears that the influence of accumulating macroalgae on the sediment system depends on the amount and the physiological status of the macroalgae. With a high load of drifting macroalgae in a stagnant situation, the structure and function of the sediment community are strongly affected. No significant flow of organic material from the macroalgal mat to the sediment system could be proven. The macroalgal mat apparently constitutes an independent habitat, which influences the sediment community by shading and, when mineralization is fast, by creating unfavourable conditions via low oxygen values.
\end{abstract}

\section{INTRODUCTION}

During the last decade there has been a major reevaluation of the general view of marine pelagic food webs. Through the use of new sampling techniques the importance of bacteria, flagellates and ciliates in the pelagic energy flow has been discovered. In benthic systems the importance of the microscopic food web has long been recognized. A large number of investigations have dealt with the different 'compartments' of benthic systems, i.e. bacteria, microscopic algae, protozoa and small metazoa, but few studies exist where most or all of these groups are assessed simultaneously.

\footnotetext{
- Present address: Tjärnö Marine Biological Laboratory, Pl. 2781, S-452 00 Strömstad, Sweden

There is still a lack of studies on the relative importance of these groups in terms of numbers and biomass, let alone studies that deal with rates of energy flow (cf. Jansson \& Wulff 1977, Montagna 1984, Admiraal et al. 1988, Bouvy 1988).

Twenty years ago the suggestion that large-scale man-induced eutrophication of the sea was in process would most probably have been met with suspicion by scientists, politicians and the public. Today eutrophication of the sea is a subject of intense public debate in Sweden (Larsson et al. 1985, Rosenberg 1985, Fleischer et al. 1987, Rosenberg \& Loo 1988), and massive plankton blooms and large-scale bottom anoxia have been reported from other coastal areas as well (e.g. Nielsen \& Artebjerg 1984, Weigelt \& Rumohr 1986, Lancelot et al. 1987), One possible effect of eutrophication, easily 
seen by the public, is the accumulation of vast quantities of macroscopic algae in shallow sheltered bays and on sandy beaches (McComb et al. 1979, Nicholls et al. 1981, Reise 1983, Rosenberg 1985, Wennberg 1987). Little is known about the effect of this accumulation on the community of sandy sediments, in particular the lower trophic levels of the food web.

By using an outdoor experimental set-up we aimed at studying to what extent and how the accumulation of filamentous macroalgae, in quantities found in nature, affects the structure and function of a shallow-water sandy sediment community. Estimates of structural changes were based on relationships between numbers and biomass of bacteria, autotrophs, micro- and meiofauna and their qualitative composition. Effects on the functional level were assessed by measuring primary productivity, changes in carbon pools and oxygen and nutrient fluxes.

\section{MATERIAL AND METHODS}

Experimental set-up. The effect of accumulation of drifting macroalgae on a sediment community was studied in an outdoor flow-through system at Tjärnö Marine Biological Laboratory near Stromstad on the west coast of Sweden $\left(58^{\circ} 52^{\prime} \mathrm{N}, 11^{\circ} 09^{\prime} \mathrm{E}\right)$. Twelve circular $30 \mathrm{l}$ containers were placed in a frame of timber fixed between 2 rafts; a roof of transparent PVC prevented contamination by rain and seabird faeces (Fig. 1). Sandy sediment was collected from a nearby shallow bay $(0.2 \mathrm{~m}$ water depth) in 2 layers (the top $1 \mathrm{~cm}$ was scraped off and kept separate) and sieved (mesh size $500 \mu \mathrm{m}$ ) to remove macrofauna [mainly juveniles of the polychaete Hediste diversicolor O. F. Müller and the bivalve Cerastoderma edule (L.)]. The sand was homogenized and spread out in 2 layers $(2 \mathrm{~cm}$ of surface sediment on top of a $8 \mathrm{~cm}$ thick bottom layer) on the bottom (area $0.1 \mathrm{~m}^{2}$ ) of each container. Seawater from $2 \mathrm{~m}$ depth was pumped up and filtered through 2 cotton-filter cartridges $(50$ and 1 um; Vattenteknik, Malmö, Sweden) before it reached a 50 I cistern (Fig.
1). The water flow to each container was controlled by a rollerclamp on each tube $(6 \mathrm{~mm}$ i.d. $)$, so that a turnover time of roughly $10 \mathrm{~h}$ was established $\left(1.5 \mathrm{l} \mathrm{h}^{-1}\right)$. To allow the vertical chemocline to stabilize, the containers were allowed to equilibrate for $11 \mathrm{~d}$ before the experiment was started. The experiment was run for 3 wk (9 to 31 August 1987). During this period the temperature of the overlying water varied between 14.5 and $19.5^{\circ} \mathrm{C}$.

Fresh filamentous red algae (mainly Rhodomela, Polysiphonia and Ceramium spp.) were collected by diving, and were then rinsed with seawater to remove fauna and epiphytes. We chose to use filamentous red algae because they tend to accumulate in sheltered shallow areas in late summer and autumn and have also been reported to form wracks on the shores of the west coast of Sweden (Wennberg 1987). An amount of $1.8 \mathrm{~kg}$ fresh weight (FW) per $\mathrm{m}^{2}$, corresponding to the natural amount of drifting macroalgae in a nearby sandy bay, was added to 4 containers (referred to as high dose) and half the amount $\left(0.9 \mathrm{~kg} \mathrm{FW} \mathrm{m}^{-2}\right)$ to 4 other containers (referred to as low dose). These additions initially reduced the light (photon flux density measured by Biosphere quantameter in sunlight at noon) at the sediment surface by about $90 \%$ in the high-dose and by $70 \%$ in the low-dose containers. Four containers without addition of macroalgae served as controls. At the end of the experiment the remaining macroalgae were collected, dried and weighed.

Sampling. On each sampling occasion 2 to 3 cores were taken for each organism group from each container, using a cut-off plastic syringe (diameter $22 \mathrm{~mm}$ for meiofauna, chlorophyll a and primary productivity; diameter $9 \mathrm{~mm}$ for autotrophic microflora, bacteria and ciliates). The top $5 \mathrm{~mm}$ of the sediment was used for analyses. A test showed that $90 \%$ of the meiofauna occurred in this layer. Samples $(600 \mathrm{ml})$ from the overlying water were taken for analyses of dissolved inorganic nutrients $\left[\mathrm{NH}_{4}{ }^{+}, \mathrm{NO}_{3}{ }^{-}+\mathrm{NO}_{2}^{-}, \mathrm{PO}_{4}{ }^{3-}\right.$ and $\mathrm{Si}(\mathrm{OH})_{4}$ ]. Samples were taken once a week, though oxygen concentration was measured more frequently (see Fig. 10).

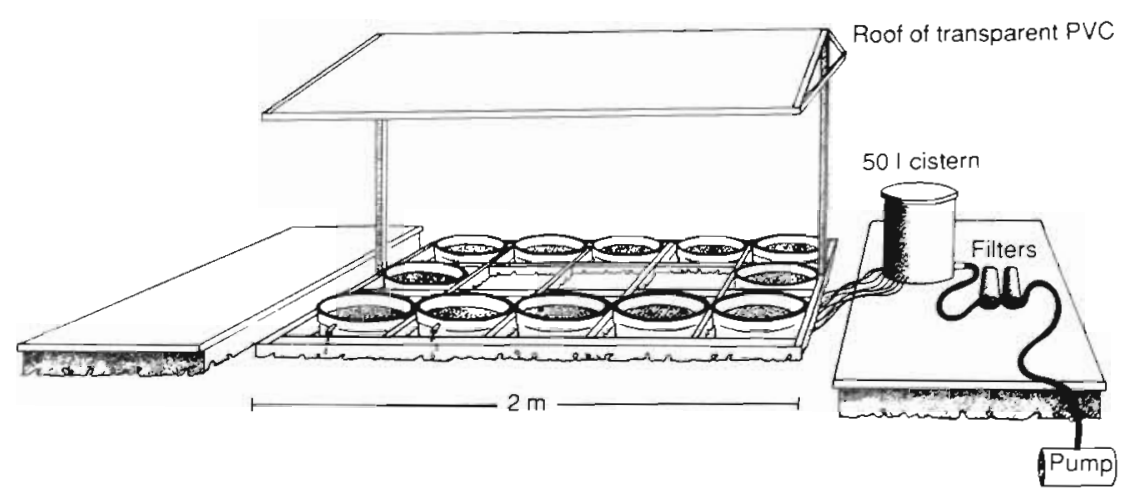

Fig. 1. The outdoor experimental set-up 
Primary productivity and chlorophyll a. For microphytobenthic productivity and chlorophyll a content, 3 sediment cores were taken from each container; 2 cores were pooled and treated as one sample and one was kept separate. Chlorophyll a content was analysed according to Lorenzen (1967) after extraction with $90 \%$ acetone overnight and 5 min of ultrasonication. The benthic primary production was measured as ${ }^{14} \mathrm{C}$ uptake in subsamples taken with a glass tube $(5.8$ $\mathrm{mm}$ i.d.) from the homogenized pooled sample. The sediment was spread out in glass vials, and $25 \mathrm{ml}$ of filtered seawater and $0.15 \mathrm{ml}$ of $\mathrm{H}^{14} \mathrm{CO}_{3}$ solution (3 $\mu \mathrm{Ci}$ ) were added. The vials were placed upside down on the bottom of each container and incubated for $2 \mathrm{~h}$ (10:00 to 12:00 h). The samples were filtered on 0.2 $\mu \mathrm{m}$ PC-filters (Nuclepore $\left.{ }^{\circledR}\right)$, put into scintillation vials, 2 drops of $0.1 \mathrm{M} \mathrm{HCl}$ were added and the filters were dried at $60^{\circ} \mathrm{C}$. The organic matter and filters were dissolved with $1 \mathrm{ml}$ of Soluene ${ }^{\circledR}-350$ and then, after $8 \mathrm{~h}, 15 \mathrm{ml}$ of scintillation mixture (Hionic-Fluor ${ }^{\mathrm{TM}}$ ) were added. The samples were counted in a LKBWallac 1217 liquid scintillation counter. Total carbon dioxide concentration in the water and carbon assimilated were calculated using equations in Ertebjerg Nielsen \& Bresta (1984). All values were corrected for dark fixation and converted to daily production using insolation values obtained by a Kipp and Zonen solarimeter placed on the laboratory roof. Since incubations were made with the sediment spread out in the incubation bottles, productivity values were corrected to 'intact core' using a factor of 0.4 (Cadée \& Hegeman 1974).

Although the inflowing seawater was filtered, we measured ${ }^{14} \mathrm{C}$ uptake in the overlying water to check for phytoplankton growth, by incubating one light and one dark vial from one container of each treatment

Algal cells. The number of living autotrophic cells was counted using epifluorescence microscopy. Two sediment samples from each container were pooled. diluted with filtered seawater to a volume of $6 \mathrm{ml}$, and ultrasonicated (Sonorex RK 100) for $10 \mathrm{~min}$. This treatment detached most of the epipsammic cells, but apparently did not break cells, since motile cells could be seen in sonicated samples. Fluorescent cells were counted in a Bürker counting chamber. Cells were grouped into size and shape classes and identified as far as possible to genus level. Average cell volume and carbon content for each group were calculated according to Edler $(1977,1979)$. The factor to convert cell volume to carbon varied between 0.085 and 0.11 .

Ciliates. Ciliates were extracted by a modified version of the seawater-ice method (Fenchel 1967). The samples were transferred to plastic test tubes $115 \mathrm{~mm}$ i.d.) with a bottom of nylon gauze (mesh size $100 \mu \mathrm{m}$ ), and covered with cotton and seawater ice. The nylon gauze was brought into contact with $0.2 \mu \mathrm{m}$-filtered seawater in a Nunc M24 multivial (Nunc AS, Denmark) for $1 \mathrm{~h}$, which probably extracted ca $80 \%$ of the ciliates (own preliminary testing; Fenchel 1967). The ciliates were preserved in Lugol's solution and counted within $12 \mathrm{~h}$ in an inverted microscope at $\times$ 250, differentiating into 3 size classes (length $<50$, $50-150,>150 \mu \mathrm{m})$. The biovolume of 30 individuals from the medium and large size classes were measured in the microscope by squeezing them between glass slides as described by Fenchel (1967). Ciliates smaller than $50 \mu \mathrm{m}$ were assigned a volume of 10000 $\mu^{3}$ (Jonsson 1987). Biovolume was converted to carbon using conversion factors AFDW $=0.15 \times$ volume (Finlay \& Uhlig 1981) and carbon $=0.43 \times$ AFDW (Fenchel \& Finlay 1983).

Meiofauna. Sediment cores were preserved in $4 \%$ borax buffered formalin containing rose bengal. The organisms were extracted by decantation (Uhlig et al. 1973). The supernatant was poured through a set of sieves with mesh sizes $0.5,0.2,0.1$ and $0.04 \mathrm{~mm}$. The remaining heavy residue was checked for dense organisms (mainly foraminiferans, ostracodes and bivalves). The number of organisms in each size fraction was sorted into major taxa and counted under a low power microscope at $\times 25$ to 50 . The number of organisms in each size fraction was used for conversion into AFDW, as given in Widbom (1984). AFDW was converted to carbon using a factor of 0.45 (Båmstedt 1986).

Bacteria. Samples were preserved in $4 \%$ boraxbuffered $0.2 \mu \mathrm{m}$-filtered formalin. The number of bacterial cells was counted using acridine orange epifluorescence microscopy (Hobbie et al. 1977). Samples were shaken with $1 \mathrm{M} \mathrm{KCl}$ for 1 h to break electrostatic interactions (M.-O. Samuelsson pers. comm.) and homogenized for $30 \mathrm{~s}$. Two filters were prepared from each core and the number of bacteria on 10 microscopic fields were counted on each filter. The biovolume of 20 bacterial cells from each core was measured, assuming a spherical shape for cocci and a cylindrical shape for rods. Volume was converted to carbon using the same conversion factors as for ciliates.

Particulate organic carbon (POC) and nitrogen (PON). The contents of POC and PON of dried and homogenized sediment and macroalgal samples were measured using a Heraeus CHN-O-RAPID elemental analyser. For POC analyses, the sediment samples were treated with $2.5 \mathrm{M} \mathrm{HCl}$ for $30 \mathrm{~min}$ at $40^{\circ} \mathrm{C}$ to remove inorganic carbon. Sediment samples were taken on Days 1, 16 and 23, and macroalgal samples were taken on Days 1 and 23.

oxygen. The oxygen concentration in the inflowing water (in the cistern) and in the unstirred overlying water in the experimental containers was measured 
with a YSI Model 58 oxygen electrode. During the measurements the electrode was kept 1 to $2 \mathrm{~cm}$ above the sediment surface.

Inorganic nutrients. Samples for analyses of $\mathrm{NH}_{4}{ }^{+}$, $\mathrm{NO}_{3}{ }^{-}+\mathrm{NO}_{2}{ }^{-}, \mathrm{PO}_{4}{ }^{3-}$ and $\mathrm{Si}(\mathrm{OH})_{4}$ were taken from the water cistern and, after stirring, from the overlying water of each experimental container. The samples were immediately filtered (Whatman GF/F, retension capacity $0.7 \mu \mathrm{m}$ ) and nutrients were analysed according to methods described by Carlberg (1972)

Statistical analysis. Visual inspection of data-plots and variance-ratio tests indicated that data were not normally distributed and that variances were nonhomogeneous. Application of Taylor's power law (Green 1979) suggested a $\overline{x+1}$ transformation. Inspection of transformed data showed that the transformation was successful in reducing non-normality and heterogeneity of variances. The effect of treatments on different variables was tested by a 2-way nested ANOVA (Underwood 1981, p. 585). Further comparisons between different means were tested by using Newman-Keuls multiple comparison test (NK), with differences accepted as significant when $\mathrm{p}<$ 0.05 .

\section{RESULTS}

\section{Visual observations}

The containers within each treatment behaved very similarly with one exception (see below). In the control containers the sediment surface kept a light-brownish colour during the entire experiment. In the low-dose containers the macroalgae floated at the water surface throughout the experiment (bubbles, most likely oxy- gen, were formed in the algal mat). In the high-dose containers, the macroalgae soon turned into a greyish mat floating just above the sediment surface, which turned black within $2 \mathrm{wk}$, and a smell of $\mathrm{H}_{2} \mathrm{~S}$ was noted. At the end of the experiment, the sediment surface in these containers turned more light-coloured as a result of improved oxygen conditions. One of the 4 high-dose containers, however, behaved more like a low-dose container (cf. oxygen flux values below). We did not exclude this container from the statistical data sets, but in order to clarify differences between treatments, we give 2 means where $n=4$ or 3 .

\section{Autotrophic microflora}

There was no consistent difference between treatments in the biomass of sediment-associated microalgae (ANOVA, $\mathrm{p}>0.05$ ), but there was a significant difference between days (ANOVA, $p \leq 0.01$ ). The number and biomass of the microalgae did not change significantly in the control containers during the course of the experiment ( $\mathrm{NK}, \mathrm{p}>0.05$ ), being about 70 to 80 $\times 10^{9}$ cells $\mathrm{m}^{-2}$ corresponding to 650 to $700 \mathrm{mg} \mathrm{C} \mathrm{m}^{-2}$ (Fig. 2). In the low-dose containers, the microalgal biomass first increased (by $200 \mathrm{mg} \mathrm{m}^{-2}$ during the first week), mainly due to the growth of filamentous cyanophytes, and then declined slightly, but was qualitatively similar to the control containers: small (5 to 20 $\mu \mathrm{m}$ ) naviculoid diatoms and plate-shaped cyanophyte colonies (Merismopedia and Microcrocis spp.) together with filamentous cyanophytes (Oscillatoria and Phormidium spp.) made up most of the biomass (Fig. 2). In the high-dose containers the biomass of viable microalgae grew qualitatively differently (plate-shaped cyanophyte colonies dominated over thread-like

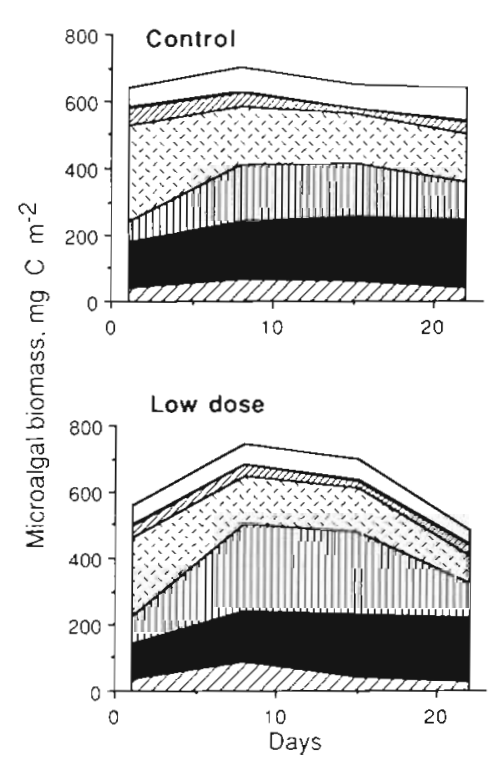

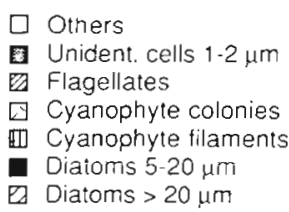

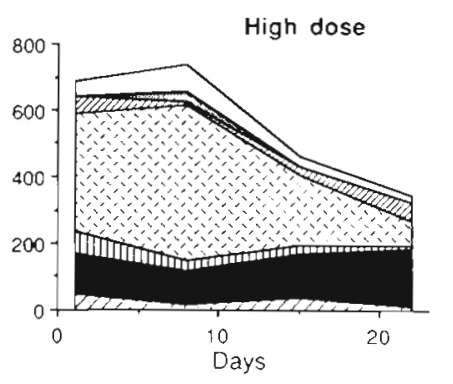

Fig. 2. Biomass and composition of autotrophic benthic microflora in the top $5 \mathrm{~mm}$ sediment Curves are based on means of 4 replicate containers. Control $=$ containers with no addition of macroalgae; low dose = addition of $0.9 \mathrm{~kg} \mathrm{FW}$ $\mathrm{m}^{-2}$ of filamentous red algae; high dose $=$ addi . tion of $1.8 \mathrm{~kg} \mathrm{FW} \mathrm{m}^{-2}$ of filamentous red algae 
cyanophytes) and at the end of the experiment the total biomass had significantly decreased (by $50 \%$ ) from the initial value (NK, $\mathrm{p} \leq 0.05)$, whereas the biomass of diatoms remained unchanged (Fig. 2).

\section{Chlorophyll a}

The mean chlorophyll a content of the sediment varied between 40 and $90 \mathrm{mg} \mathrm{m}^{-2}$ (Fig. 3), but there was no significant difference between the treatments until Day 23, when values in the control containers were significantly higher than in the low- and highdose treatments (NK, $\mathrm{p} \leq 0.05)$.

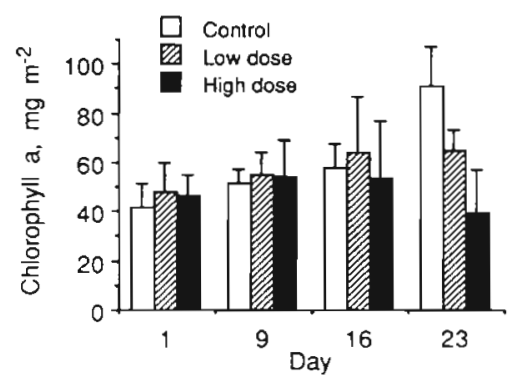

Fig. 3. Chlorophyll a content in the top $5 \mathrm{~mm}$ sediment. Each bar shows mean $+\mathrm{SD}(\mathrm{n}=4)$. For explanation of treatments see Fig. 2

\section{Ciliates}

Ciliate numbers and biomass decreased in all treatments as the experiment continued (Fig. 4). There was a significant difference between treatments (ANOVA, $p \leq 0.05$ ) and between dates (ANOVA, $p \leq 0.001$ ). There was no significant difference between containers at the start of the experiment (mean values $1.1 \times 10^{7}$ individuals $\mathrm{m}^{-2}$ corresponding to about $60 \mathrm{mg} \mathrm{C} \mathrm{m}^{-2}$ ), but with time ciliate numbers and biomass in the highdose containers decreased most and from Day 9 onwards they were significantly lower than in the control and low dose containers (NK, $\mathrm{p} \leq 0.05$ ) (Fig. 4).

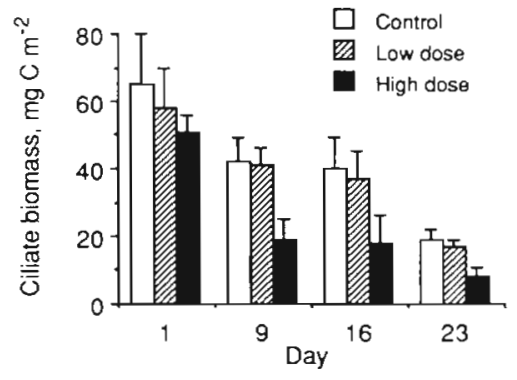

Fig. 4. Biomass of ciliates in the top $5 \mathrm{~mm}$ sediment. Each bar shows mean $+S D(n=4)$. For explanation of treatments see Fig. 2

\section{Meiofauna}

The meiofauna populations were strongly affected by the high-dose addition of organic material. The biomass of total meiofauna differed between treatments (ANOVA, $p \leq 0.025$ ) and between days (ANOVA, $p \leq$ 0.01 ), and a significant treatments $x$ time interaction term (ANOVA, $\mathrm{p} \leq 0.001$ ) shows that treatments developed differently with time. The biomass of the total meiofauna in the control and low-dose containers increased (from $250 \mathrm{mg} \mathrm{C} \mathrm{m}^{-2}$ on Day 1 to $560 \mathrm{mg} \mathrm{C} \mathrm{m}^{-2}$ on Day 23 for control and from 220 to $570 \mathrm{mg} \mathrm{C} \mathrm{m}^{-2}$ for low-dose), while it decreased in the high-dose containers (from $260 \mathrm{mg} \mathrm{C} \mathrm{m}^{-2}$ on Day 1 to $150 \mathrm{mg} \mathrm{C} \mathrm{m}^{-2}$ on Day 23) (Fig. 5). On Days 16 and 23 the biomass in the highdose containers was significantly lower than in the control and low-dose containers (NK, $\mathrm{p} \leq 0.05)$. The composition of meiofauna also differed between treatments (Fig. 5). The control and low-dose containers developed towards a diverse community, where harpacticoid copepods, rotifers and foraminiferans occurred in large numbers and where ostracodes and bivalves were important in terms of biomass (Fig. 5). The high-dose containers developed in the same way at first, but after Day 9 these groups declined and a community dominated by nematodes began developing.

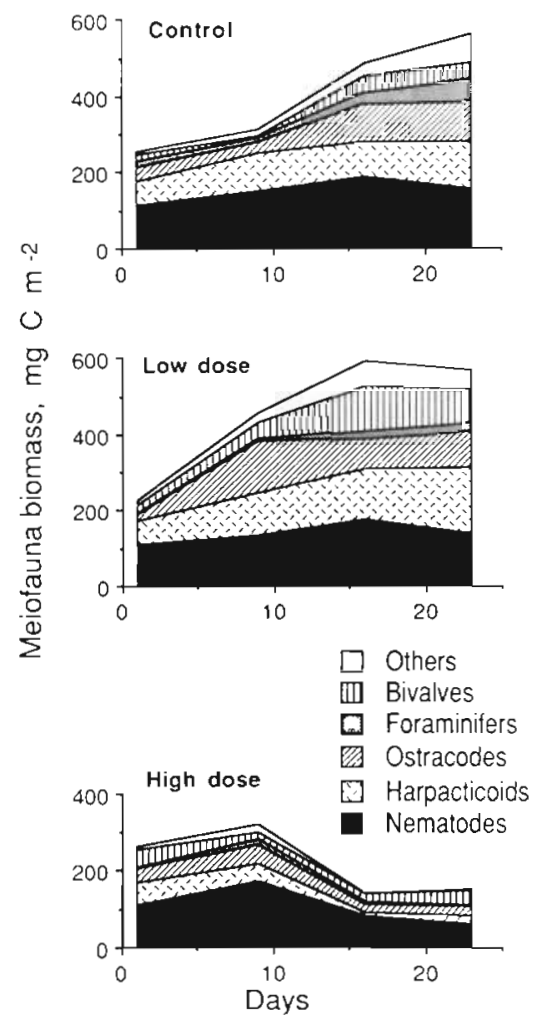

Fig. 5. Biomass and composition of meiofauna in the top $5 \mathrm{~mm}$ sediment. Curves are based on means of 4 replicate containers. For explanation of treatments see Fig. 2 


\section{Bacteria}

We could not detect any clear trend in the number and biomass of bacteria. The biomass of bacteria varied only slightly in this experiment (between 90 and $190 \mathrm{mg} C$ $\mathrm{m}^{-2}$ ) (Fig. 6), and no significant differences between times and treatments could be found (ANOVA, $p>0.05$ ). The average biovolume per individual cell did not differ significantly between treatments, and varied between 0.2 and $0.5 \mu \mathrm{m}^{3}$ during the experiment.

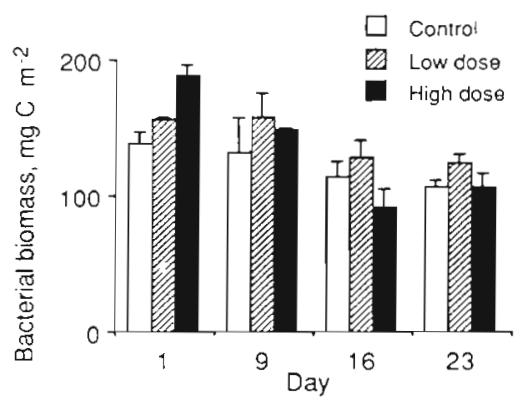

Fig. 6. Biomass of bacteria in the top $5 \mathrm{~mm}$ sediment. Each bar shows mean $+\mathrm{SD}(\mathrm{n}=4)$. For explanation of treatments see Fig. 2

\section{Proportions of organism groups}

Initially, living autotrophic microalgae constituted $58 \%$ of the carbon associated with living biota (Fig. 7). This proportion decreased to $46 \%$ in the control and $40 \%$ in the low-dose treatment at the end of the experiment, but did not change significantly in the high-dose containers. The most obvious change in the control and low-dose containers was that the proportion of meiofauna increased from an initial $23 \%$ to a final $42 \%$ (their biomass had already doubled after $2 \mathrm{wk}$ ), while in the high-dose containers the proportion of meiofauna did not change, although its composition and biomass were altered (see above). Ciliates initially accounted for the least part of the living biota $(5 \%)$, and decreased to about $1 \%$ in all treatments. The proportion of bacteria was $15 \%$ in control and low-dose and increased to $20 \%$ in the high-cose treatment.

\section{POC and PON}

Addition of filamentous algae initially corresponded to $71.2 \mathrm{~g} \mathrm{~m}^{-2}$ (high dose) and $35.6 \mathrm{~g} \mathrm{~m}^{-2}$ (low dose) of organic carbon ( $\mathrm{C} / \mathrm{N}$ mole ratio 9.7 ). The $\mathrm{POC}$ in the macroalgal mat decreased by $13.2 \mathrm{~g} \mathrm{C} \mathrm{m}^{-2}$ (mean rate $0.6 \mathrm{mg} \mathrm{m}^{-2} \mathrm{~d}^{-1}$ ) in the low-dose containers and by 51.7 $\mathrm{g} \mathrm{C} \mathrm{m}^{-2}$ (mean rate $2.4 \mathrm{mg} \mathrm{m}^{-2} \mathrm{~d}^{-1}$ ) in the high-dose containers, corresponding to a decrease of 37 and $73 \%$,
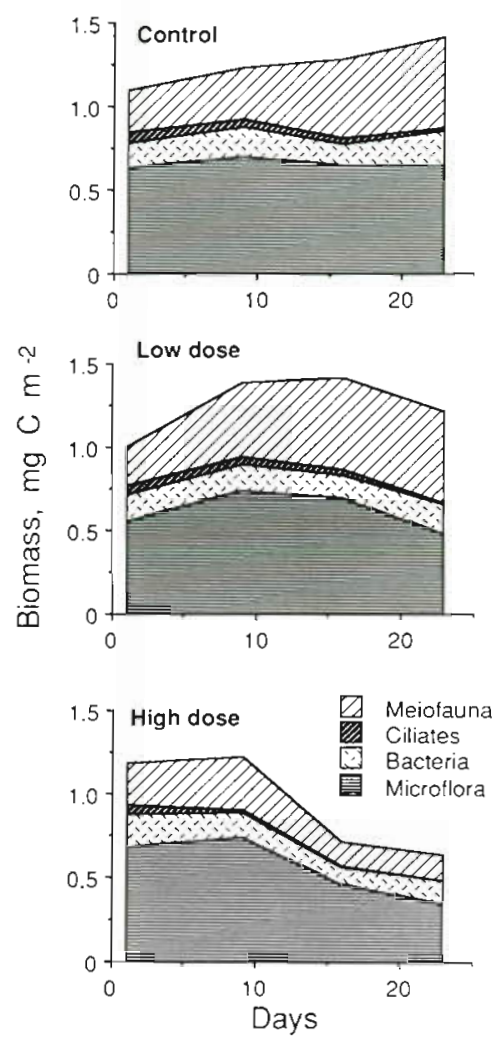

Fig. 7 Total biomass of living organisms and proportions between organism groups in the top $5 \mathrm{~mm}$ sediment. Curves are based on means of 4 replicate containers. For explanation of treatments see Fig. 2

respectively, The PON values decreased by 45 and $61 \%$, respectively and thus, at the end of the experiment there was a significant difference between the $\mathrm{Cl}$ $\mathrm{N}$ mole ratio of the macroalgal biomass in the low-dose $(\mathrm{C} / \mathrm{N} 11.2)$ and the high-dose (C/N 6.8) treatments. The mean initial POC content of the sand was $10.9 \mathrm{~g} \mathrm{~m}^{-2}$. At the end of the experiment the carbon contents in both the control and low-dose containers had increased. though not significantly (NK, p > 0.05), by $2 \mathrm{~g} \mathrm{~m}^{-2}$ (Fig. 8), corresponding to a mean rate of $95 \mathrm{mg} \mathrm{C} \mathrm{m}^{-2} \mathrm{~d}^{-1}$. The increase rate was highest $\left(200 \mathrm{mg} \mathrm{C} \mathrm{m}^{-2} \mathrm{~d}^{-1}\right.$ ) during the first $2 \mathrm{wk}$ in the control containers (Fig. 8). In the high-dose containers, the carbon content decreased significantly by $2.3 \mathrm{~g}(\mathrm{NK}, \mathrm{p} \leq 0.05)$, corresponding to a mineralization rate of 110 to $126 \mathrm{mg} \mathrm{C} \mathrm{m}^{-2} \mathrm{~d}^{-1}$ The initial content of PON in the sediment $\left(1.6 \mathrm{mg} \mathrm{m}^{-2}\right)$ did not change significantly in the control containers, and increased, though not significantly, by $0.4 \mathrm{mg} \mathrm{m}^{-2}$ $(25 \%)$ in the low-dose treatment. In high-dose containers the $\mathrm{N}$-content decreased significantly by $0.6 \mathrm{mg}$ $\mathrm{m}^{-2}$ or $38 \%(\mathrm{NK}, \mathrm{p} \leq 0.05)$. The initial $\mathrm{C} / \mathrm{N}$ mole ratio of the sediment was $8.0(\mathrm{CV}=7.5 \%)$ and no significant change could be seen at the end of the experiment nor between the treatments. 


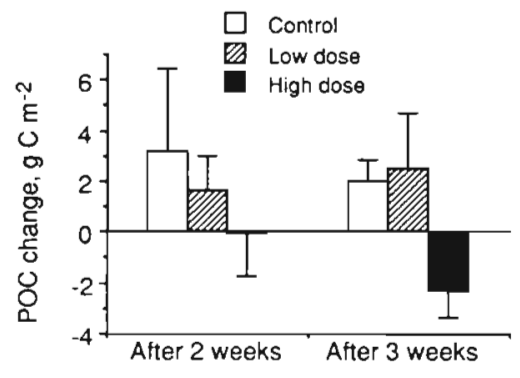

Fig. 8. Changes in the content of particulate organic carbon in the top $5 \mathrm{~mm}$ sediment. Each bar shows mean $+\mathrm{SD}(\mathrm{n}=4)$. For explanation of treatments see Fig. 2

\section{Primary productivity in the sediment}

Microphytobenthic primary productivity in the lowdose containers (160 to $310 \mathrm{mg} \mathrm{C} \mathrm{m}^{-2} \mathrm{~d}^{-1}$ ) did not differ significantly from the control (190 to $270 \mathrm{mg} \mathrm{C} \mathrm{m}^{-2} \mathrm{~d}^{-1}$ ) (Fig. 9), whereas the values for the high-dose treatment decreased significantly (NK, $\mathrm{p} \leq 0.05)$. After about $2 \mathrm{wk}$ these values were only one-third $\left(80 \mathrm{mg} \mathrm{C} \mathrm{m}^{-2}\right.$ $\mathrm{d}^{-1}$ ) of the control values, but there was a slight increase at the end of the experiment (Fig. 9). Primary productivity in the overlying water varied between 0 and $10 \mathrm{mg} \mathrm{C} \mathrm{m} \mathrm{m}^{-2} \mathrm{~d}^{-1}$, which is at most $6 \%$ (mean $2.3 \%$ ) of the sediment primary productivity.

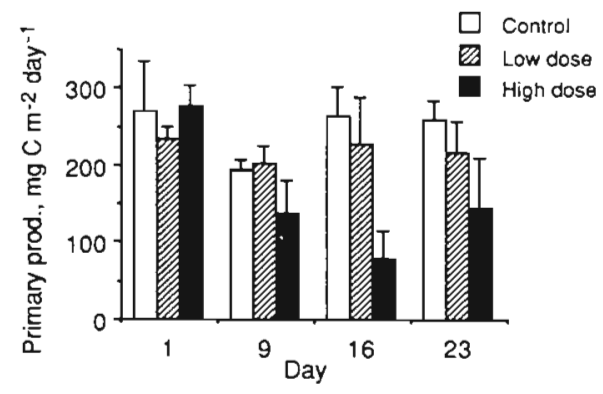

Fig. 9. Microbenthic primary productivity in the top $5 \mathrm{~mm}$ sediment. Each bar shows mean $+\mathrm{SD}(\mathrm{n}=4)$. For explanation of treatments see Fig. 2

\section{Oxygen flux}

Oxygen concentrations in the low-dose containers varied between 5 and $>20 \mathrm{mg} \mathrm{l}^{-1}$ and did not differ significantly from those in the control containers (NK, $p>0.05$ ). Calculation of oxygen fluxes indicated that the system in these containers was autotrophic $(P>R)$ most of the time, with the mean maximum net rate of oxygen production being $140 \mathrm{mg}$ in the control and $170 \mathrm{mg} \mathrm{O} \mathrm{m}^{-2} \mathrm{~h}^{-1}$ in the low-dose treatment (Fig. 10). Occasional diurnal measurements showed that the oxygen concentrations were highest in the late after- noon and early evening and lowest in early morning. Since we normally measured oxygen concentrations at 09:00 h, our values are likely to represent rather low values. In the high-dose containers oxygen concentrations fell sharply to values close to $0 \mathrm{mg} \mathrm{l}^{-1}$ within a week (except in one container), thus exhibiting a net oxygen consumption most of the time (maximum mean rate $110 \mathrm{mg}$ if $\mathrm{n}=4$ and $135 \mathrm{mg} \mathrm{O} \mathrm{m}^{-2} \mathrm{~h}^{-1}$ if $\mathrm{n}=3$ ) (Fig. 10). Towards the end of the experiment (Days 20 and 22) a net production of oxygen was observed in the high-dose containers.

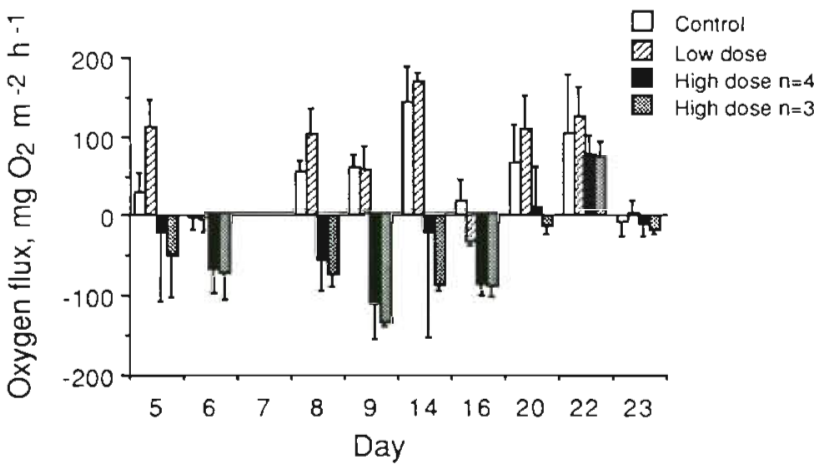

Fig. 10. Oxygen flux in the overlying water. Positive values = net production, negative values = net consumption. Each bar shows mean $+\mathrm{SD}(\mathrm{n}=3$ and 4$)$. For explanation of treatments see Fig. 2

\section{Inorganic nutrients}

Concentrations of inorganic $\mathrm{N}$ and $\mathrm{P}$ in the surface water (= inflow) were low during the entire experiment $\left(\mathrm{NH}_{4}{ }^{+}<2 \mu \mathrm{M}, \mathrm{NO}_{3}{ }^{-}+\mathrm{NO}_{2}{ }^{-}<0.5 \mu \mathrm{M}\right.$, and $\mathrm{PO}_{4}{ }^{3-}<0.1$ $\mu \mathrm{M})$. The ammonium flux differed between treatments and days as shown by a significant interaction term in the ANOVA ( $\mathrm{p} \leq 0.005)$. There was no significant difference between the ammonium flux in the control and the low-dose containers; $\mathrm{NH}_{4}{ }^{+}$was released in the beginning of the experiment (mean rate of $170 \mu \mathrm{mol}$ $\mathrm{m}^{-2} \mathrm{~d}^{-1}$ ), but was later taken up at a maximum rate of $530 \mu \mathrm{mol} \mathrm{m} \mathrm{m}^{-2} \mathrm{~d}^{-1}$ (Fig. 11a). In the high-dose containers $\mathrm{NH}_{4}{ }^{+}$values increased significantly $(\mathrm{NK}, \mathrm{p} \leq 0.05)$ in connection with low oxygen values at a mean rate of up to $1.4(2.1$ when $\mathrm{n}=3) \mathrm{mmol} \mathrm{m}^{-2} \mathrm{~d}^{-1}$ (Fig. 11a), except in one container in which oxygen values did not drop and $\mathrm{NH}_{4}{ }^{+}$was instead taken up at the same rate as in the control and low-dose treatments.

The flux of $\mathrm{NO}_{3}{ }^{-}+\mathrm{NO}_{2}{ }^{-}$(mainly uptake varying between 10 and $150 \mu \mathrm{mol} \mathrm{m} \mathrm{m}^{-2} \mathrm{~d}^{-1}$ ) did not differ significantly between treatments (ANOVA, p > 0.05) but between days (ANOVA, $\mathrm{p} \leq 0.001$ ) (Fig. 11b). From Day 9 to Day 16, however, there was a significant increase in the disappearance rate of $\mathrm{NO}_{3}{ }^{-}+\mathrm{NO}_{2}{ }^{-}$in the high-dose treatment ( $N K, p \leq 0.05$ ) (Fig. 11b).

Phosphate concentrations in the overlying water 
were close to the limit of detection and thus the calculated flux rates should be interpreted with caution. The $\mathrm{PO}_{4}{ }^{3-}$ flux rates were low $\left(+30\right.$ to $\left.-30 \mu \mathrm{mol} \mathrm{m}{ }^{-2} \mathrm{~d}^{-1}\right)$ (Fig. 11). The variation among replicate treatments was high and no significant difference was observed between treatments (ANOVA, $\mathrm{p}>0.05$ ). With time, however, there was a significant change in the direction of fluxes, from efflux on Day 1 to uptake on Day 23 (ANOVA, $\mathrm{p} \leq 0.001$ ).

Silicate concentration of the inflowing surface water varied between 4 and $8 \mu \mathrm{M}$ during the experiment. The ANOVA showed that treatments developed differently with time (treatments $\times$ time interaction term $p \leq 0.01$ ) An uptake of silicate was observed in all containers, mean values of treatments varying between 250 and 2050 umol $\mathrm{m}^{-2} \mathrm{~d}^{-1}$ with no significant difference between treatments except once: silicate was released at a maximum rate of $400 \mu \mathrm{mol} \mathrm{m} \mathrm{m}^{-2} \mathrm{~d}^{-1}$ in the highdose containers in connection with low oxygen values $($ NK, $\mathrm{p}<0.05)$ (Fig. 11d)

\section{DISCUSSION}

\section{Experimental set-up}

The advantages and disadvantages of enclosures such as micro- and mesocosms, as compared with field experiments, have previously been discussed (Bloesch 1988 and references therein). The greater precision of measurements, gained by easier sampling and replication and adequate control treatments, is achieved at the price of creating a more or less artificial situation. In our experiment we sieved the sediment, excluded epifauna, prevented immigration and emigration, and altered the wave impact. In order to measure the flux of nutrients, it was also necessary to maintain a controlled low rate of water exchange. The 'healthy' look of control containers, however, indicated that we had not decreased this rate below that necessary to sustain a normal community. Since microfauna and bioturbation (e.g. Kristensen \& Blackburn 1987) as well as water exchange and wave forces tend to prevent anoxia in sediments, our set-up probably amplified the effect of the treatments. Stagnant situations, where detached macroalgae or detritus can remain in the same place, are however not uncommon in sheltered bays and on sublittoral sediments (e.g. Hylleberg \& Henriksen 1980, own obs.).

We can use the estimated population densities of the control containers to see how natural our experimental set-up was. The number and biomass of benthic microflora, as well as chlorophyll a content, of the sediment was within the range of values reported for sandy sediment in temperate areas (Plante et al. 1986 and references therein). Since microphytobenthos and diatoms are commonly regarded as synonyms (with the exception of salt marshes, where cyanophytes are common; e.g. Kaas 1987), it is noteworthy that initially only about one-third of the living microfloral biomass consisted of diatoms, the rest being mainly cyanophytes and various flagellates. This was probably due to the time of the year and the type of sediment used, i.e. sand from a brackish non-tidal area, which lacks the dense, vertically migrating epipelic diatom flora typical of tidal flats (Admiraal 1984, Paterson 1986), a habitat from which hitherto most investigations on marine and brackish-water microphytobenthos originate.
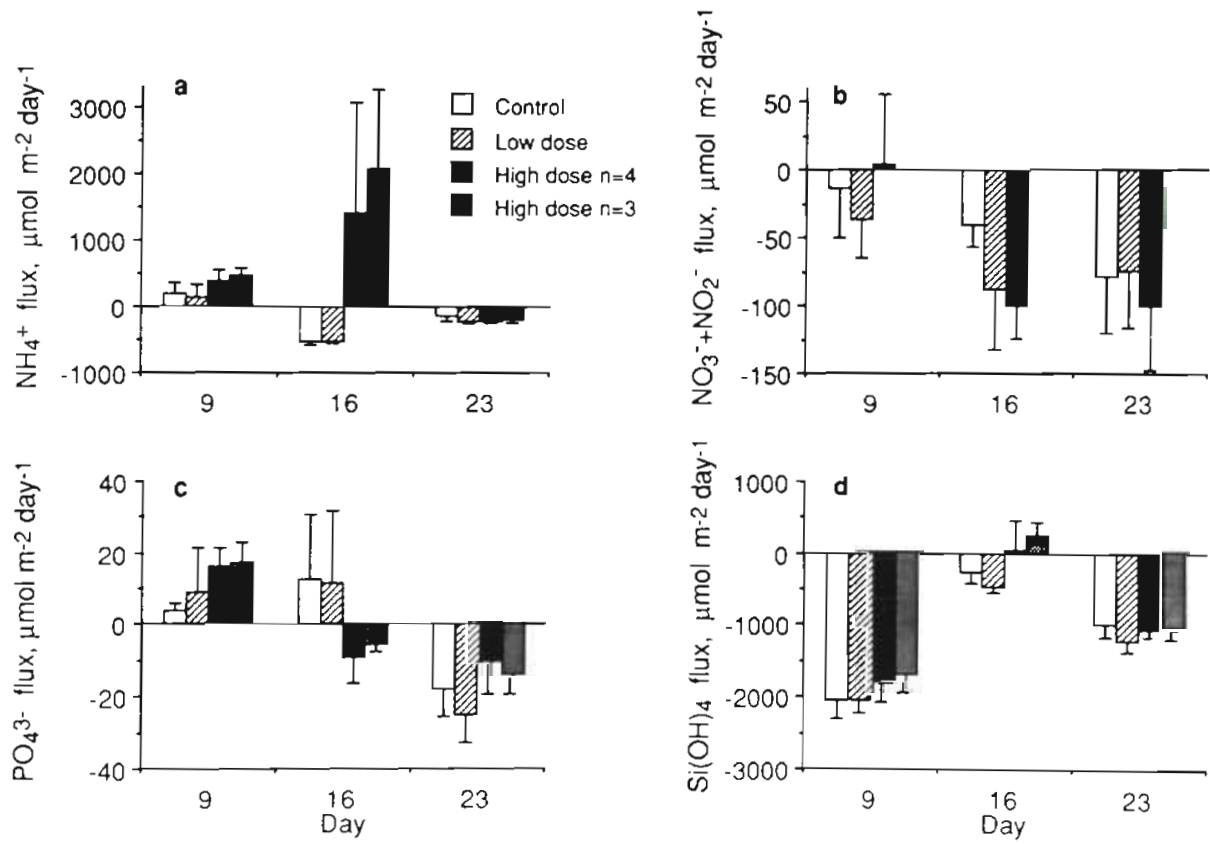

Fig. 11. Rates of decrease and increase of (a) $\mathrm{NH}_{4}{ }^{+}$. (b) $\mathrm{NO}_{3}{ }^{-}+$ $\mathrm{NO}_{2}^{-}$, (c) $\mathrm{PO}_{4}{ }^{3-}$ and (d) $\mathrm{Si}(\mathrm{OH})_{4}$ in the overlying water. Each bar shows mean + SD ( $n=3$ and 4 ). For explanation of treatments see Fig. 2 
Our values for total meiofauna ( 1 to $2 \times 10^{6}$ individuals $\mathrm{m}^{-2}$ ) and AFDW (around 0.5 to $1 \mathrm{~g} \mathrm{~m}^{-2}$ ) are typical values for this kind of sediment and sampling methods (Rudnick et al. 1985). From being dominated mainly by nematodes and harpacticoids on Day 1, the control containers developed a more diverse community. The ciliate populations declined most likely as a consequence of our experimental arrangement; the decrease of water movement over the sediment resulted in the blocking of interstitia by detritus and autotrophs. Fenchel $(1969,1978)$ showed that benthic ciliates can be very specific in their requirements of food, sediment particle sizes and oxygen profile, and they are in general least numerous in non-capillary sediments. The number and biomass found for the controls in our experiment $\left(5 \times 10^{6}\right.$ to $1.25 \times 10^{7}$ individuals $\mathrm{m}^{-2}$ and 0.3 to $1.1 \mathrm{~g}$ wet wt $\mathrm{m}^{-2}$ ) are typical values for ciliates in fine sand (Fenchel 1969).

Bacterial numbers and biomass found in control containers at the beginning and during the experiment are similar to those normally found in silty sand (Cammen 1982, Montagna 1982, Branch \& Pringle 1987, Bianchi 1988).

Considered as a total - the biomass, density and proportions of organisms in control containers - the system does not indicate an unnatural structure, but approximately mimics a situation where a sandy sediment under stagnant conditions is gradually converted to a less capillary sediment.

\section{Effect of macroalgal addition on the structure of the sand ecosystem}

The addition of organic material either did not change the community composition to any significant degree (low dose) or changed the composition completely (high dose). We had expected that a moderate amount (low dose) of macroalgae would stimulate bacterial activity and in the end also increase the pool of nutrients available to the microphytobenthos (Owens \& Stewart 1983, Levinton 1985). This would have led to an increased amount of food available for ciliates and meiofauna. If they were limited by the amount of food, a greater increase in populations in low-dose containers than in control containers would have been expected. But neither bacteria nor microphytobenthos increased significantly more in low-dose containers compared with control containers. This means that we do not know if the meiofauna and ciliates were foodlimited in this experiment. Since they were not significantly fewer in the low-dose containers than in control containers, the low-dose treatment did not deteriorate the conditions either (at least not until the last date), which is also supported by the oxygen values. The lack of response might have been due to a lag time, which was not revealed by our 3 wk experiment. In a field experiment, Levinton (1985) found that detritus derived from Ulva, which was blended, dried and mixed with the sediment, subsidized diatom growth only after a 2 to 3 wk lag time

The high-dose community, on the other hand, did soon deteriorate, which quickly showed in microalgal, meiofauna and ciliate abundances. In the microalgal assemblage, a change in the species composition preceeded a decrease in the biomass. Levinton (1985) found that detritus addition initially depressed diatom standing stock. Despite the $50 \%$ decrease of the total microalgal biomass in our experiment, the diatom biomass was unaltered, which most likely demonstrates the capacity of benthic diatoms to tolerate anoxic conditions and sulfides (Admiraal 1984, Kennett \& Hargraves 1985, Sundbäck \& Granéli 1988). Low oxygen values during the middle of the experiment probably caused death of ciliates and most meiofauna groups. Nematodes did survive, although only in low numbers, which agrees with what has been found in several pollution studies (e.g. Widbom \& Elmgren 1988). Ciliates were almost eradicated, which is puzzling since many ciliate species have the ability to tolerate anoxia and high levels of $\mathrm{H}_{2} \mathrm{~S}$ (Fenchel 1969). All the sediment that we put into the containers was oxygenated, so it is possible that no strictly anaerobic ciliates initially occurred in the containers, and also our experimental set-up prevented immigration from underlying anoxic sediments. Since the anaerobic ciliate community can be very diverse and abundant (Fenchel 1969), our set-up might have underestimated the ciliate activity that would occur in these sediments in nature.

The experiment was run for $3 \mathrm{wk}$ and we do not know for certain whether the difference between lowdose and high-dose containers would have persisted, or if the low-dose containers after a time lag would have developed in a similar way as did the high-dose containers. However, since the amount of carbon added in the low-dose containers was $50 \%$ of the amount added in the high-dose containers, the deteriorating, if any, would most certainly be less drastic than in the high-dose containers.

\section{Effect of macroalgal addition on the carbon pool}

The addition of drifting macroalgal biomass could theoretically mean 2 alternative impacts on the function of the sediment ecosystem. (1) The productivity in the sediment would increase because of the extra source of energy and nutrients derived from allochthonous organic matter (see discussion above), an effect that is in accordance with the view that marine 
sandy shallow areas are dependent on the import of organic carbon (e.g. Postma 1988). However, recent investigations from tidal sandy areas have also shown that autochthonous primary production may cover the food requirements of the benthos (Asmus \& Asmus 1985, Reise 1985, Biological Research Ems-Dollard Estuary 1985). (2) Alternatively, the sediment below a (decomposing) macroalgal mat would turn into an unfavorable habitat with low oxygen concentrations (cf. Nicholls et al. 1981); even the oxygen-producing microphytobenthic photosynthesis would be eliminated through lack of light. The floating algal mat would then, at least temporarily, be a more favourable habitat for organisms, if they were capable of taking advantage of this new habitat (cf. Reise 1983), and the local biological activity would then move from the sediment up to the algal mat. Emigration to uncovered refuges, as found by Reise (1983), was not allowed in our experimental set-up. The new habitat would also favour epibenthic animals (Nicholls et al. 1981). We did not investigate the floating macroalgal mat separately (except for POC and PON content), and thus we could only get indirect information of processes in this habitat. A microscopic examination showed that the macroalgal mat in the low-dose containers sustained a dense epiphytic and microfaunal community, indicating a diverse and high biological activity.

The input of organic carbon in the form of filamentous algae was about 6 times (high dose) and 3 times (low dose) the initial amount of sediment POC, i.e. a considerable potential carbon source. The fact that the carbon content of the sediment in the high-dose containers decreased indicates that there was no significant direct input of POC from the macroalgal mat to the sediment. The number of bacteria in the sediment did not increase either. This agrees with the results of Levinton (1985), who suggested that bacterial productivity rather than abundance would respond to a detritus addition. Apparently most of the macroalgal carbon was mineralized in the algal mat itself, and was released as $\mathrm{CO}_{2}$ and as dissolved organic matter (DOM), which we did not measure. The difference between the final $\mathrm{C} / \mathrm{N}$ mole ratio of the macroalgae in low and high doses (11.2 and 6.8, respectively) may be due to a qualitative change in the algal mat with time, e.g. by the addition of new material in the low-dose containers through production (cf. Kristensen \& Blackburn 1987). The mineralization was fast: in high dose treatments $>70 \%$ carbon disappeared within 3 wk. Schmidt (1978) found that the mineralization rate of macroalgae was highly dependent on temperature and that under aerobic conditions $40 \%$ of the red algal carbon disappeared at $15^{\circ} \mathrm{C}$ during a $14 \mathrm{~d}$ decomposition experiment. Koop et al. (1982), who investigated mineralization of kelp on a beach, found that $70 \%$ of the carbon was lost as $\mathrm{CO}_{2}$ to the atmosphere, while $28 \%$ passed to bacteria. They also found high DOM concentrations beneath decomposing kelp. The increase of sediment carbon in the low-dose treatment (equal to the increase in the controls) was likely due to sediment primary production, since the magnitude of increase in living microalgal biomass, ${ }^{14} \mathrm{C}$-uptake and POC were about the same in the control and low-dose containers. Furthermore, the increase of pheopigments was the same in the control and low-dose containers, indicating that pheopigments too were mainly of microphytobenthic origin. Thus the overstory of decomposing macroalgae seems to have constituted an independent system that influenced the energy flow of the sand ecosystem only indirectly through shading and changing the oxygen (and possibly nutrient) conditions. The lack of coupling between the sediment and the algal mat can perhaps be partly a result of the fact that the macroalgal filaments were floating above the sediment surface and not buried into the sediment, as has been shown to be the case for, for example, detached green algae in other studies (Hylleberg \& Henriksen 1980, Owens \& Stewart 1983). An other reason might be the initial absence of epifaunal grazing and fragmentation in the algal mat.

Only about $10 \%$ of the initial POC of the sediment originated from living organisms, according to our calculations based on biovolumes. This agrees with the results of Cammen (1982), who found a large unidentified POC pool with a $\mathrm{C} / \mathrm{N}$ weight ratio near $7(=8.2$ mole ratio), i.e. close to our mean $\mathrm{C} / \mathrm{N}$ ratio $(8.0)$. Initially the microalgae made up $5.8 \%$, bacteria $1.5 \%$, ciliates $0.5 \%$ and meiofauna $2.3 \%$ of the total sediment POC. These values agree well with those found by others in similar sediments. Cammen (1982) found that bacteria always accounted for less than $2 \%$ and according to Bianchi (1988) benthic diatoms made up 3 to $6 \%$ of the total POC, while bacteria only accounted for 0.01 to $0.03 \%$. There is, however, one group of organisms that we were not able to include in our calculations of the living biomass, i.e. heterotrophic flagellates. For example, more than half of the dinoflagellate species found on sandy substrates in the Danish Wadden Sea are confined to heterotrophic nutrition (Larsen 1985).

Our methods for calculating biomass from biovolumes may include several sources of error that lead to underestimations of the carbon content. Since a large part of microalgal carbon can be associated with dead (not fluorescent) cells, counting living (= fluorescent) algal cells underestimated the total microalgal carbon. Increasing pheopigment values during the experiment indicated increase of dead algal cells, most probably through grazing. If the microalgal biomass is instead calculated from chlorophyll a values using a 
mean C/chl a ratio of 40 (de Jonge 1980, Cammen and Walker 1986), we obtain an initial value of $1.8 \mathrm{~g} \mathrm{C} \mathrm{m}^{-2}$, which is 3 times higher than our mean value calculated from biovolumes $\left(0.63 \mathrm{~g} \mathrm{C} \mathrm{m}^{-2}\right)$. Our initial $\mathrm{C} / \mathrm{chl}$ a ratios (calculated from carbon values based on biovolumes) varied between 12 and 15, but decreased during the experiment to final values of 7 to 8 . However, we do not know if these low ratios reflect natural highly variable ratios (de Jonge 1980) or methodological problems. In containers with macroalgal addition the lowered ratio might also reflect shade adaptation by the microalgae, i.e. an increase of the chlorophyll a content per cell.

The increase of sediment carbon between Day 1 and Day $23\left(2 \mathrm{~g} \mathrm{~m}^{-2}\right.$ based on elemental analyses) in the top $0.5 \mathrm{~cm}$ sediment of the control and low-dose containers could only to a minor part (16 and $10 \%$, respectively) be traced as increased biomass of living organisms (smaller than $0.5 \mathrm{~mm}$ ) and was mainly due to increased meiofaunal biomass. This indicates that processes turning living biomass into accumulating detritus are rapid and agrees with what Asmus \& Asmus (1985) found for the grazing food chain on a sandy tidal flat. In the highdose containers $24 \%$ of the POC decrease could be traced to decreased biomass of living organisms.

In the control containers the only source of increase in sediment carbon was the microphytobenthic primary production, calculated to be $5.2 \mathrm{~g} \mathrm{C} \mathrm{m}^{-2}$ for the whole experimental period based on ${ }^{14} \mathrm{C}$-uptake. About $40 \%$ of this value was observed as an increase of the sediment POC at the end of the experiment, and thus about $60 \%$ of the assimilated carbon was probably lost via respiration and as DOM. This indicates that in the control containers the autochthonous primary productivity was high enough to support the energy demand of the benthos and in the end also explain the increase of the meiofaunal biomass.

An addition of $0.9 \mathrm{~kg} \mathrm{FW} \mathrm{m} \mathrm{m}^{-2}$ of macroalgae hardly changed the flows of oxygen when compared with the controls. The benthic primary productivity was not significantly lowered either, which would have been expected from the shading of the algal mat, thus suggesting shade adaptation of the benthic microalgae. The increased respiration and mineralization caused by the macroalgal addition were apparently balanced by primary production by the macroalgae and their epiphytes (diatoms and cyanophytes), since the oxygen production in the low-dose containers corresponded to that of the control containers. When the amount of drifting macroalgae was doubled a threshold was passed and both the structure and the functioning of the ecosystem was altered.

Although the rapid decomposition of macroalgae in the high-dose containers created a low-oxygen situation, which led to dark coloured sediment with $\mathrm{H}_{2} \mathrm{~S}$ production, the microphytobenthos did partly retain their photosynthetic capacity. The ability of the sediment microflora to recover fast was demonstrated by both increased microbenthic primary productivity and axygen production at the end of the experiment, which has also been shown in previous experiments (Admiraal 1984, Sundbäck \& Granéli 1988).

\section{Inorganic nutrients}

The experiment was run during August, a period with low concentrations of inorganic nutrients in the surface water (caused by dinoflagellate blooms) characteristic for late-summer situations. Several recent investigations have demonstrated the influence of microphytobenthos on the nutrient flux between sediment and water (Carlton \& Wetzel 1988, Hansson 1988, Kelderman et al. 1988, Sundbäck \& Granéli 1988). The microflora controls flux both by uptake from the overlying water and by regulating redox-sensitive processes, such as adsorption/desorption of phosphorus and ammonium flux, by photosynthetical oxygen production (Carlton \& Wetzel 1988, Sundbäck \& Granéli 1988).

Assuming a $\mathrm{C} / \mathrm{N}$ mole ratio of 10 (Brzezinski 1985) and a mean daily primary production of $250 \mathrm{mg} \mathrm{C} \mathrm{m}^{-2}$ for the control containers (Fig. 9), the sediment microflora would have needed $2.1 \mathrm{mmol}^{\mathrm{N} \mathrm{m}} \mathrm{m}^{-2} \mathrm{~d}^{-1}$, i.e. 3.5 times the recorded maximum disappearance of inorganic $\mathrm{N}\left(\mathrm{NH}_{4}{ }^{+}+\mathrm{NO}_{3}{ }^{-}+\mathrm{NO}_{2}{ }^{-}\right)$from the overlying water. To this is added the requirements of bacteria (Wheeler \& Kirchman 1986). This indicates either that the microphytobenthos was nitrogen-limited or that the main part was taken up from the pore water, which usually contains an order of magnitude higher concentrations than the overlying water (cf. Granéli \& Sundbäck 1985). Regenerated ammonium might also have been rapidly recirculated within the benthic system. We do not know either to what extent the benthic microalgae may have used DON, such as free amino acids, as nitrogen source (Flynn \& Butler 1986 and references therein). If we assume that 30 to $40 \%$ of the primary production in the control containers was accounted for by diatoms, then the silicate uptake would be in the range 2.1 to $2.8 \mathrm{mmol}$ $\mathrm{m}^{-2} \mathrm{~d}^{-1}$ (Si/C mole ratio 0.34; Marker \& Casey 1982), which is of the same magnitude as the maximum uptake we measured.

It is difficult to interpret the role of the macroalgal mat for the nutrient fluxes from our data on inorganic nutrients. There was in most cases no significant difference between treatments. The macroalgae and associated bacteria could be expected either to compete for nutrients or release nutrients through mineralization. At least in the high-dose containers, where mineralization was fast, it would have been reasonable to expect a 
raised level of inorganic nutrients. Both processes were probably operating simultaneously, in particular in the low-dose containers where the macroalgae were covered by a dense assemblage of epiphytes. Thus, during the experiment the nutrients seem to have been circulated within the algal mat itself (cf. McComb et al. 1979, Owens \& Stewart 1983).

In the high-dose containers ammonium was released concomitantly with the low oxygen values. Microphytobenthic photosynthesis was not able to balance the high rate of oxygen consumption, thus accelerating the release of ammonium, which may have originated from the macroalgal mat as well as from the sediment. However, in this study phosphorus was not released, which is in contrast to what has previously been found in oxygen-depleted situations (e.g. Enoksson 1987, Carlton \& Wetzel 1988, Sundbäck \& Granéli 1988). On the other hand the simultaneous release of silicate was probably caused by a decreased Si-uptake by benthic diatoms (cf. Kelderman et al. 1988), since silicate flux is not considered to be redox-sensitive.

In conclusion, our experiment suggests that the impact of the accumulation of drifting macroalgae on the sediment community involves a threshold effect, which depends on the amount and the physiological status of the algae. With a large load of drifting macroalgae in a stagnant situation, the structure, and consequently the functioning, of the sediment community is strongly affected. We could not prove any significant flow of organic material from the algal mat to the sediment during the course of our 3 wk experiment. Inorganic nutrients (mainly ammonium) were released only when oxygen values were very low, and must therefore have been circulated within the macroalgal cover. The algal mat apparently constitutes an independent habitat, which influences the sediment community by shading and, when mineralization is fast, by creating unfavourable conditions via low oxygen values. Since our experimental set-up excluded factors such as wave impact and changes in the direction of currents, which may remove the algal mat, as well as emigration and immigration of organisms, our conclusions need to be verified by in situ investigations where both the sediment and the algal mat are studied.

\footnotetext{
Acknowledgements. Tjänö Marine Biological Laboratory provided excellent working facilities during the experiment. We thank Professor Inger Wallentinus (Dept of Marine Botany) and Dr Per Jonsson (Tjärnö Marıne Biological Laboratory) for cntically reading the manuscript. Financial support was provided by National Swedish Environmental Protection Board, Swedish Natural Science Research Council, The Royal Swedish Academy of Sciences (The Anna-Greta and Holger Crafoord Fund and J. A. Ahlstrand Fund for Zoological Studies), The Royal Society of Arts and Sciences in Gothenburg and the Donation Fund of Captain Carl Stenholm.
}

\section{LITERATURE CITED}

Admiraal, W (1984). The ecology of estuarine sedimentinhabiting diatoms. In: Round, F. E., Chapman, D. J. (eds.) Progress in phycological research, Vol. 3, Biopress, Bristol, p. 269-322

Admiraal, W., Arkel van, M. A., Baretta, J. W., Colijn, F., Ebenhöh, W., Jonge de, V N., Kop, A., Ruardij, P., Schröder, H. G. J. (1988). The construction of the benthic submodel. In: Baretta, J. W., Ruardij, P. (eds.) Tidal flat estuaries: simulation and analysis of the Ems estuary. Ecological studies, Vol. 74. Springer-Verlag, Berlin, p. 105-151

Frtebjerg Nielsen, G., Bresta, A.-M. (1984). Guidelines for the measurements of phytoplankton primary production. Baltic Mar. Biol. (BMB) Publ. No. I, 2nd edn, Charlottenlund

Asmus, H., Asmus, R. (1985). The importance of grazing food chain for energy flow and production in three intertidal sand bottom communities of the northern Wadden Sea. Helgoländer Meeresunters. 39: 273-301

Båmstedt, U. (1986). Chemical composition and energy content. In: Corner, E. D. S., O'Hara, S. C. M. (eds.) The biological chemistry of marine copepods. Oxford University Press, Oxford. p. 1-58

Bianchi, T S. (1988). Feeding ecology of subsurface depositfeeder Leitoscoloplos fragilis Verrill. I. Mechanisms affecting particle availability on intertidal sandflat. J. exp. mar. Biol. Ecol. 115: 79-97

Bloesch, J. (1988). Mesocosm studies. Hydrobiologia 159: $221-222$

Biological Research Ems-Dollard Estuary (BOEDE) (1985). Rijkswaterstaat Communications No. 40. The Hague

Bouvy, M. (1988). Contribution of the bacterial and microbenthic microflora in the energetic demand of the meiobenthos in an intertidal muddy sediment (Kerguelen Archipelago). P.S.Z.N.I. Mar Ecol. 9: 109-122

Branch, G. M., Pringle, A. (1987). The impact of the sand prawn Callianassa kraussi Stebbing on sediment turnover and on bacteria, meiofauna, and benthic microflora. J. exp. mar. Biol. Ecol. 107: 219-235

Brzezinski, M. A. (1985). The Si: C:N ratio of marine diatoms: interspecific variability and the effect of some environmental variables. J. Phycol. 21: 347-357

Cadée, G. C., Hegeman, J. (1974). Primary production of the benthic microflora living on tidal flats in the Dutch Wadden Sea. Neth. J. Sea Res 8: 260-291

Cammen. L. M. (1982). Elfect of particle size or organic content and microbid abundance within four marine sediments. Mar. Ecol. Prog. Ser. 9: 273-280

Cammen, L. M., Walker, J. A. (1986). The relationship between bacteria and micro-aigae in the sediment of a Bay of Fundy mudflat. Estuar cstl Shelf. Sci. 22: 91-99

Carlberg, S. (ed.) (1972). New Baltic manual with methods for sampling and analyses of physical, chemical and biological parameters. ICES Coop. Res. Rept Ser. A, Vol. 29

Carlton, R. G., Wetzel, R. G. (1988) Phosphorus flux from lake sediments: effect of epipelic algal oxygen production. Limnol. Oceanogr 33: 562-570

Edler, L. (1977). Phytoplankton and primary production in the Sound. Ph.D thesis, Unuversity of Lund

Edler, L. (ed.) (1979). Recommendations on methods for marine blological studies in the Baltic Sea. Phytoplankton and chlorophyll. Baltic Mar Biol. (BMB) Publ. No. 5, p. $1-38$

Enoksson, V (1987). Nitrogen flux between sediment and water and its regulatory factors in coastal areas. Ph.D. thesis, University of Göteborg 
Fenchel, T. M. (1967). The ecology of marine microbenthos I. The quantitative importance of ciliates as compared with metazoans in various types of sediments. Ophelia 4: $121-137$

Fenchel, T M. (1969). The ecology of marine microbenthos. IV. Structure and function of the benthic ecosystem, its chemical and physical factors and the microfauna communities with special reference to the ciliated protozoa. Ophelia 6: 1-182

Fenchel, T M. (1978). The ecology of micro- and meiobenthos. Ann. Rev. Ecol. Syst. 9: 99-121

Fenchel, T M., Finlay, B. J. (1983). Respiration rates in heterotrophic, freeliving Protozod. Microb. Biol. 9: 99-122

Finlay, B. J., Uhlig, G. (1981). Calorific and carbon values of marine and freshwater protozoa. Helgoländer Meeresunters. 34: 401-412

Fleischer, S., Hamrin, S., Kindt, T., Rydberg, L., Stibe, L. (1987). Coastal eutrophication in Sweden: reducing nitrogen in land runoff. Ambio 16: 246-251

Flynn, K. J., Butler, I. (1986). Nitrogen sources for the growth of marine microalgae: role of dissolved free amino acids. Mar. Ecol. Prog. Ser. 34: 281-304

Granéli, E., Sundbäck, K. (1985). The response of planktonic and microbenthic algal assemblages to nutrient enrichment in shallow coastal waters, southwest Sweden. J. exp. mar Biol. Ecol. 85: 253-268

Green, R. H. (1979). Sampling design and statistical methods for environmental biologists. John Wiley and Sons, New York

Hansson, L.-A. (1988). Effects of competitive interactions on the biomass development of planktonic and periphytic algae in lakes. Limnol. Oceanogr. 33: 121-128

Hobbie, J. E., Daley, R. J., Jasper, S. (1977). Use of Nuclepore filters for counting bacteria by fluorescence microscopy. Appl. environ. Microbiol. 33: 1225-1228

Hylleberg, J., Henriksen, K. (1980). The central role of bioturbation in sediment mineralization and element re-cycling. Ophelia, Suppl. 1. 1-16

Jansson, B.-O., Wulff, F. (1977). Ecosystem analysis of a shallow sound in the Northern Baltic - A joint study by the Askö group. Contr Askö Lab. No. 18

Jonge, V.N. de (1980). Fluctuations in the organic carbon to chlorophyll a ratios for estuarine benthic diatom populatjons. Mar Ecol. Prog. Ser 2: 345-353

Jonsson, P. R. (1987). Photosynthetic assimilation of inorganic carbon in marine oligotrich ciliates (Ciliophora, Oligotrichina). Mar. Microb. Food Webs 2: 55-68

Kaas, H. (1987). Algal studies of the Danish Wadden Sea. V. Blue-green algae in higher salt marsh areas - their seasonal and spatial distribution. Nord. J. Bot. 7: 735-749

Kelderman, P., Lindeboom, H. J., Klein, J. (1988). Light dependent sediment-water exchange of dissolved reactive phosphorus and silicon in a producing microflora mat. Hydrobiologia 159: 137-147

Kennett, D. M., Hargraves, P. E. (1985). Benthic diatoms and sulfide fluctuations: upper basin of Pettaquamscutt River, Rhode Island, Estuar. cstl Shelf Sci. 21: 577-586

Koop. K., Newell, R. C., Lucas, M. I. (1982). Microbial regeneration of nutrients from the decomposition of macrophyte debris on the shore. Mar. Ecol. Prog. Ser. 9: 91-96

Kristensen, E., Blackburn, T H. (1987). The fate of organic carbon and nitrogen in experimental marine sediment systems: influence of bioturbation and anoxia. J. mar. Res. 45: 231-257

Lancelot, C., Billen, G., Sournia, A., Weisse, T., Colijn, F., Veldhuis, M. J. W., Davies, A., Wassman, P. (1987). Phaeocystis blooms and nutrient enrichment in the con- tinental coastal zones of the North Sea. Ambio 16: 38-46 Larsen, J. (1985). Algal studies of the Danish Wadden Sea II. A taxonomic study of psammobious dinoflagellates. Opera Bot. 79: 14-37

Larsson, U., Elmgren, R.. Wulff, F. (1985) Eutrophication and the Baltic Sea: causes and consequences. Ambio 14: 9-14

Levinton, J. S. (1985). Complex interactions of a deposit feeder with its resources: roles of density, a competitor, and detrital addition in the growth and survival of the mudsnail Hydrobia totteni. Mar. Ecol. Prog. Ser. 22: 31-40

Lorenzen, C. J. (1967). Determination of chlorophyll and pheopigments: spectrophotometric equations. Limnol. Oceanogr. 12: 343-346

Marker, A. F. H., Casey, H. (1982). The population and production dynamics of benthic algae in an artificial recirculating hard-water stream. Phil. Trans. R. Soc. Lond. B 298: 265-308

McComb, A. J., Atkins, R. P., Birch, P. B., Gordon, D. M., Lukatelich, R. J. (1979). Eutrophication in the Peel-Harvey estuarine system, western Australia. In: Neilson, B. J., Cronin, L. E. (eds.) Estuaries and nutrients. Humana Press, Clifton, New Jersey, p. 323-342

Montagna, P. A. (1982). Sampling design and enumeration statistics for bacteria extracted from marine sediments. Appl. environ. Microbiol. 43: 1366-1372

Montagna, P. A. (1984). In situ measurement of meiobenthic grazing rates on sediment bacteria and edaphic diatoms. Mar. Ecol. Prog. Ser 18: 119-130

Nicholls, D. J., Tubbs, C. R., Haynes, F. N. (1981). The effect of green algal mats on intertidal macrobenthic communities and their predators. Kieler Meeresforsch., Sonderh. 5: $511-520$

Nielsen, A., Ertebjerg, G. (1984). Plankton blooms in Danish waters. Ophelia, Suppl. 3: 181-188

Owens, N. J. P., Stewart, W. D. P. (1983). Enteromorpha and the cycling of nitrogen in a small estuary. Estuar cstl Shelf Sci. 17. 287-296

Paterson, D. M. (1986). The migratory behaviour of diatom assemblages in a laboratory tidal micro-ecosystem examined by low temperature scanning electron microscopy. Diat. Res. 1: 227-239

Plante, R., Plante-Cuny, M.-R., Reys, J.-P. (1986). Photosynthetic pigments of sandy sediments on the north Mediterranean coast: their spatial distribution and its effect on sampling strategies. Mar Ecol. Prog. Ser. 34: 133-141

Postma, H. (1988). Tidal flat areas. In: Jansson, B.-O. (ed.) Coastal-offshore ecosystem interactions. Lecture notes on coastal and estuarine Studies, Vol. 22. Springer-Verlag, Berlin, p. 102-121.

Reise, K. (1983). Sewage, green algal mats anchored by lugworms, and the effects on Turbellaria and small Polychaeta. Helgoländer Meeresunters. 36: 151-162

Reise, K. (1985). Tidal flat ecology. An experimental approach to species interactions. Ecological Studies 54. Springer Verlag, Berlin

Rosenberg, R. (1985). Eutrophication - the future marine coastal nuisance? Mar. Pollut. Bull. 16: 227-231

Rosenberg, R., Loo, L.-O. (1988). Marine eutrophication induced oxygen deficiency effects on soft bottom fauna, western Sweden. Ophelia 29: 213-225

Rudnick, D. T., Elmgren, R., Frithsen, J. B. (1985). Meiofaunal prominence and benthic seasonality in a coastal marine ecosystem. Oecologia (Berl.) 67: 157-168

Schmidt, C. (1978). Untersuchungen zum Stoffumsatz und zur Dynamik von Abbauprozessen bei benthischen Makroalgen und Seegras der Kieler Bucht (Westliche Ostsee). 
Reports Sonderforschungsbereich 95, No. 41, Kiel University, Kiel

Sundbäck, K., Granéli, W. (1988). Influence of microphytobenthos on the nutrient flux between sediment and water: a laboratory study. Mar. Ecol. Prog. Ser. 43: 63-69

Uhlig, G., Thiel, H., Gray, J. S. (1973). The quantitative separation of meiofauna. A comparison of methods. Helgoländer wiss. Meeresunters. 25: 173-195

Underwood, A. J. (1981). Techniques of analysis of variance in experimental marine biology and ecology. Oceanogr. mar Biol. A. Rev. 19: 513-605

Weigelt, M., Rumohr, H. (1986). Effects of wide-range oxygen depletion on benthic fauna and demersal fish in. Kiel Bay 1981-1983. Kieler Meeresforsch. 31: 124-136

This article was presented by Professor T. Fenchel, Helsingor, Denmark
Wennberg, I (1987). Long-term changes in the composition and distribution of the macroalgal vegetation in the southern part of Laholm Bay, south-west Sweden, during the last thirty years. Swedish Environment Protection Board, Rapport 3290, Stockholm

Wheeler, P. A., Kirchman, D. L. (1986). Utilization of inorganic and organic nitrogen by bacteria in marine systems. Limnol. Oceanogr. 31: 998-1009

Widbom, B. (1984). Determination of average individual dry weights and ash-free dry weights in different sieve fractions of marine meiofauna. Mar. Biol. 84: 101-109

Widbom, B., Elmgren, R. (1988). Response of benthic meiofauna to nutrient enrichment of experimental marine ecosystems. Mar Ecol. Prog. Ser. 42: 257-268

Manuscript first received; May 23, 1989

Revised version accepted: August 17, 1989 